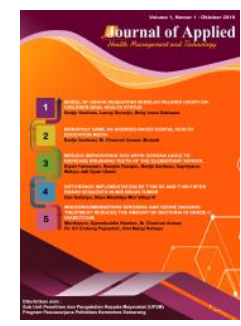

\title{
RELATIONSHIP OF SERVICE QUALITY DIMENSIONS WITH SERVICE SATISFACTION ANTENATAL CARE
}

\author{
Tri Shinta Maesaroh ${ }^{1} ;$ Elisa Ulfiana $^{2}$; Dhita Aulia Octaviana ${ }^{3}$ \\ ${ }^{1}$ Departement of Midwifery Poltekkes Kemenkes Semarang, Indonesia \\ ${ }^{2}$ Departement of Midwifery Poltekkes Kemenkes Semarang, Indonesia \\ ${ }^{3}$ Departement of Midwifery Poltekkes Kemenkes Semarang, Indonesia \\ Corresponding author: Tri Shinta Maesaroh \\ Email: tshintam@gmail.com
}

\begin{abstract}
According to data and health information from the Grobogan District Service, Puskesmas Godong II is one of the Puskesmas with the coverage of Antenatal Care lowest. In 2016 the coverage of K1 was $100 \%$, K4 was $94.42 \%$ and in $2017 \mathrm{KI}$ was $100 \%$, K4 was $93.37 \%$. The gap that occurs between $\mathrm{K} 1$ and $\mathrm{K} 4$ are due to patients feeling dissatisfied with the services provided so that patients do not make repeat visits and have an impact on the decline of in coverage Antenatal Care. The purpose of this study to determine the relationship of the dimensions of quality of service reliability (reliability), responsiveness (responsiveness), assurance (assurance), empathy (empathy), tangible (physical evidence to the satisfaction of service Antenatal Care. The study was conducted in Puskesmas Godong II with a sample of 55 pregnant women. Sampling technique with purposive sampling. The instrument used was a structured questionnaire. The data analysis used Chi-Square. The results showed the dimensions of service quality, reliability (reliability), responsiveness (responsiveness), assurance (guarantee), empathy ( empathy), tangible (physical evidence), and satisfaction, many respondents have a good perception $P$ value service quality 0.001 , reliability 0.002 , responsiveness (responsiveness) 0.010 , assurance (guarantee) 0.005, empathy (empathy) 0.009, tangible (physical evidence) 0.000 . These results indicate a relationship between the dimensions of service quality reliability (reliability), responsiveness endless (responsiveness), assurance (assurance), empathy (empathy), tangible (physical evidence) with satisfaction service Antenatal Care. It is hoped that midwives can work professionally and improve the quality of work, especially accuracy, responsiveness, skills, and friendliness, and for health centers to be able to provide good facilities and infrastructure, especially clean rooms and environments as well as complete room attributes.
\end{abstract}

Keyword : Dimensions of Service Quality, Service Satisfaction Antenatal Care

\section{Introduction}

The success of maternal health efforts can be seen from the indicator of Maternal Mortality Rate (MMR). The high rate of maternal mortality indicates low socioeconomic conditions and $\mathrm{HCF}$ include care prenatal and obstetrical low anyway ${ }^{1}$.

Factors indirect causes high rates of maternal and infant mortality include the low level of knowledge of the mother and the frequency of antenatal care is irregular. antenatal care is a service given to pregnant 
women regularly to maintain the health of mothers and their babies ${ }^{1}$.

ANC coverage in Indonesia in 2015, the percentage of $\mathrm{K} 1$ was $95.75 \%$ with $\mathrm{K} 4$ reaching $87.48 \%$ then increased in 2016 with K1 coverage of $100 \%$ but the number of $\mathrm{K} 4$ has decreased to $85.06 \% \%^{3}$. ANC coverage in 2017 has decreased from 2016, namely for the percentage of $\mathrm{K} 194.4 \%$ with $\mathrm{K} 4$ coverage is $86.57 \%{ }^{4}$.

The K1 coverage in Central Java Province in 2015 was $98.58 \%$ and for $\mathrm{K} 4$ it was $93.05 \%$. Then it increased in 2016 with K1 coverage to $99.21 \%$ and $\mathrm{K} 4$ coverage of $93.27 \%$. In 2017, ANC coverage decreased with the percentage of K1 being $98.94 \%$ and K4 by $92.53 \%{ }^{2}$.

The lowest coverage of ANC visits (K1) in 2017 was Grobogan Regency with a percentage of $85.2 \%$ and was ranked 4 th lowest in Central Java with K4 coverage of $97.4 \%$. In 2015 the coverage of $\mathrm{K} 1$ and $\mathrm{K} 4$ was $97.40 \%$ and $93.78 \%$ respectively and in 2016 for $\mathrm{K} 1$ it was $96.8 \%$ and $\mathrm{K} 491.50 \%{ }^{2}$. With the decrease in the number of ANC visits and the gap in coverage between $\mathrm{K} 1$ and $\mathrm{K} 4$, the services provided must be improved and prioritize the quality or quality of service to create satisfaction so that patients will be motivated to make ANC visits.

A research journal conducted by Maria, year 2015 at Sungai Durian Public Health Center concluded that the communication carried out by midwives had a significant relationship with the level of satisfaction of pregnant women.

Satisfaction has a significant relationship with the motivation of pregnant women in conducting visits to antenatal care. This has been expressed by Muflihatin, Chairina, and Wicaksono year 2017 in their journal entitled The Relationship between Pregnant Mother Satisfaction and Motivation visits Antenatal Care. $^{6}$

Mursyida, Mawarni \& Agushybana (2014) in their journals state that there is a relationship between perceived reliability, responsiveness, assurance, empathy, and tangibles with the satisfaction of pregnant women at ANC services ${ }^{7}$.

A preliminary study conducted by researchers on Friday, December 15, 2018, and Monday, December 182018 at the Godong II
Community Health Center of 10 pregnant women who carried out ANC showed that 2 people complained about the unclean place, 1 person stated that the officers did not maintain privacy, 2 people said the place was not comfortable, 1 person said some officers were not friendly, 1 person said the service procedure was complicated, and 3 people said they were quite satisfied with the service of the officer when carrying out antenatal careAntenatal Care. $^{7}$

Patients who were unsatisfied or dissatisfied with the services provided by the midwives at the Godong II puskesmas, some said they continued to carry out checks at the Godong II puskesmas and some chose to carry out examinations at the practice of an independent midwife, both in the same region as well as midwives outside the Godong Community Health Center. II who are considered more capable of meeting the patient's expectations in conducting or antenatal care. ${ }^{8}$

Efforts that have been made by Godong II Health Center to increase coverage include improving the skills of midwives so that there are no deviations from health service standards which can reduce the quality of health services, for example following training related to midwifery services held by the District Health Office (DKK), sharing science between midwives which is held once a week every Thursday at the Godong II Health Center, approaches mothers and families such as including families when providing counseling and engaging in decision making, applying smiles, greetings, greetings and using language that is easy for mothers to understand and always motivates mothers to regularly carry out pregnancy checks.

The Ethical Clearance of this research has been published, namely No. 26 / EA / KEPK / 2019.

\section{Methods}

The type of this researched are analytical research, with approach cross sectional and the sampling in this study using a technique in the nonprobability sampling type of purposive sampling. The number of samples in this study was 55 pregnant women. The subjects in this study were all pregnant women who were 
residents of the Godong II Community Health Center and did examinations Antenatal Care at the Puskesmas in March-April. The measuring tool in this research is a questionnaire. When the research was conducted from March 19 to April 42019 in the Godong II Health Center, Grobogan Regency. The analysis used in univariate analysis and bivariate analysis using the test Continuity Correction for 5 variables and Fisher's Exact for 1 variable provided that if $\mathrm{p}<0.05$ then $\mathrm{Ha}$ is accepted.

\section{Results and Discussion}

Table 1 Distribution of respondents based on the quality of services Antenatal Care

\begin{tabular}{llll}
\hline No. & $\begin{array}{c}\text { Kepuasan } \\
\text { pelayanan } \\
\text { Antenatal Care }\end{array}$ & $\mathrm{n}$ & $(\%)$ \\
\hline 1. & Decent & 34 & 61,8 \\
\hline 2. & Undecent & 21 & 38,2 \\
\hline & Quantity & 55 & 100,0 \\
\hline
\end{tabular}

From the table 1 results, it can be seen that the frequency distribution of the data acquisition service quality show as much as $61.8 \%$ of respondents have a good perception and as much as $38.2 \%$ of respondents have a poor perception

Table 2 Distribution of respondents based dimension Reliability

\begin{tabular}{clcc}
\hline No. & Dimension of Reliability & $\mathrm{n}$ & $(\%)$ \\
\hline 1. & Undecent & 26 & 47,3 \\
\hline 2. & Decent & 29 & 52,7 \\
\hline & Quantity & 55 & 100 \\
\hline
\end{tabular}

From the table 2 results, it can be seen that the data acquisition frequency distribution of the dimension reliability (reliability) showed as much as $47.3 \%$ of respondents have a poor perception and as much as $52.7 \%$ of respondents have a good perception.

Table 1.3 $\begin{aligned} & \text { Distribution of } \begin{array}{c}\text { Respondents by } \\ \text { Dimension } \\ \text { Responsiveness }\end{array} \\ & \text { Response }\end{aligned}$

No. Dimension of

\begin{tabular}{cccc} 
& $\begin{array}{c}\text { Responsiveness } \\
\text { (Daya Tanggap) }\end{array}$ & $\mathrm{n}$ & $(\%)$ \\
\hline 1. & Undecent & 22 & 40,0 \\
\hline 2. & Decent & 33 & 60,0 \\
\hline & Quantity & 55 & 100,0 \\
\hline
\end{tabular}

From the table 1.3 results, it can be seen that the data acquisition frequency distribution of the dimension of responsiveness (Responsiveness) showed as much as $40.0 \%$ of respondents have a poor perception and as much as $60.0 \%$ of respondents have a perception well.

Table 1.4 Distribution of Respondents based on the Dimension of Assurance (Assurance)

\begin{tabular}{cccc}
\hline No. & $\begin{array}{l}\text { Dimension of } \\
\text { Assurance }\end{array}$ & $\mathrm{n}$ & $(\%)$ \\
\hline 1. & Undecent & 10 & 18,2 \\
\hline 2. & Decent & 45 & 81,8 \\
\hline & Quantity & 55 & 100 \\
\hline
\end{tabular}

From the table 1.4 , it can be seen that the data collection of frequency distribution from the dimension of assurance (Assurance) shows that $18.2 \%$ of respondents have a poor perception and as many as $81.2 \%$ of respondents have a good perception.

Table 1.5 Distribution of Respondents by Dimension Empathy (Empathy)

\begin{tabular}{cccc}
\hline \multicolumn{2}{l}{ No. Dimension of Empathy } & $\mathrm{n}$ & $(\%)$ \\
\hline 1. & Undecent & 22 & 40,0 \\
\hline 2. & Decent & 33 & 60,0 \\
\hline & Quantity & 55 & 100,0 \\
\hline
\end{tabular}

From the table 1.5 results, it can be seen that the data acquisition frequency distribution of the dimension Empathy (Empathy) showed as much as $40.0 \%$ of respondents have a poor perception and as much as $60.0 \%$ of respondents have a good perception of

Table 1.6 Distribution of Respondents based on Tangible Dimensions (Physical Evidence)

\begin{tabular}{llll}
\hline No. & $\begin{array}{l}\text { Dimension of } \\
\text { Tangible }\end{array}$ & N & $(\%)$ \\
\hline
\end{tabular}




\begin{tabular}{clcc}
\hline 1. & Undecent & 27 & 49,1 \\
\hline 2. & Decent & 28 & 50,9 \\
\hline & Quantity & 55 & 100,0 \\
\hline
\end{tabular}

From the table above, it can be seen that the acquisition of frequency distribution data from the dimension tangible (Physical Evidence) shows that as many as $49.1 \%$ of respondents have poor perceptions and as many as $50.9 \%$ of respondents have good perceptions.

Table 1.7 Distribution of Respondents based on Antenatal Care Service Satisfaction

\begin{tabular}{lccc}
\hline No. & $\begin{array}{c}\text { Satisfaction of } \\
\text { Antenatal Care }\end{array}$ & $\mathrm{n}$ & $(\%)$ \\
\hline 1. & Decent & 27 & 49,1 \\
\hline 2. & Undecent & 28 & 50,9 \\
\hline & Quantity & 55 & 100,0 \\
\hline
\end{tabular}

From the table 1.7, it can be seen that the data collection of the frequency distribution from the satisfaction aspect shows that $49.1 \%$ of respondents feel dissatisfied and as much as $50.9 \%$ of respondents are satisfied.

Table 1.8 The Relationship between Service Quality Dimensions and Antenatal Care Service Satisfaction

\begin{tabular}{|c|c|c|c|c|c|c|c|}
\hline \multirow{3}{*}{$\begin{array}{l}\text { Service } \\
\text { Quality }\end{array}$} & \multicolumn{4}{|c|}{ Satisfaction } & \multirow{2}{*}{\multicolumn{2}{|c|}{ Quantity }} & \multirow{2}{*}{$\begin{array}{c}\mathrm{P} \\
\text { Value }\end{array}$} \\
\hline & \multicolumn{2}{|c|}{ Unsatisfied } & \multicolumn{2}{|c|}{ Satisfies } & & & \\
\hline & $\mathrm{n}$ & $\%$ & $\mathrm{n}$ & $\%$ & $\mathrm{n}$ & $\%$ & \multirow{4}{*}{0.001} \\
\hline Undecent & 17 & 81,0 & 4 & 19,0 & 21 & 100 & \\
\hline Decent & 10 & 29,4 & 24 & 70,6 & 34 & 100 & \\
\hline Quantity & 27 & 49,1 & 28 & 50,9 & 55 & 100 & \\
\hline
\end{tabular}

Results showed that the proportion of satisfaction level of patients Antenatal Care with the dissatisfied category of service quality with poor categories was $81.0 \%$ greater than the quality of service in the good category of 29 , $4 \%$. The proportion of satisfaction level of patients Antenatal Care with the satisfied category at the service quality with the poor category was $19.0 \%$ smaller than the service quality with the good category, which was $70.6 \%$.

The test used is Continuity Correction with an error rate $(\alpha)$ of $5 \%$, the result is a significant value of 0.000 , so $\mathrm{Ha}$ is accepted, so it can be concluded that there is a relationship between the dimensions of Empathy (Empathy) and the satisfaction of services Antenatal Care.

Table 1.9 Dimension Relations Reliability (Reliability) with Antenatal Care Satisfaction

\begin{tabular}{|c|c|c|c|c|c|c|c|}
\hline \multirow{3}{*}{$\begin{array}{c}\text { Dimen } \\
\text { sion of } \\
\text { Relia } \\
\text { bility }\end{array}$} & \multicolumn{4}{|c|}{ Satisfaction } & \multirow{2}{*}{\multicolumn{2}{|c|}{ Total }} & O \\
\hline & \multicolumn{2}{|c|}{ Unsatisfied } & \multicolumn{2}{|c|}{ Satisfied } & & & value \\
\hline & $\mathrm{n}$ & $\%$ & $\mathrm{n}$ & $\%$ & $\mathrm{n}$ & $\%$ & \\
\hline Undecent & 19 & 73,1 & 7 & 26,9 & 26 & 100 & \\
\hline Decent & 8 & 27,6 & 21 & 72,4 & 29 & 100 & 0,002 \\
\hline Quantity & 27 & 49,1 & 28 & 50,9 & 55 & 100 & \\
\hline
\end{tabular}

Results showed that the proportion of rate patient satisfaction Antenatal Care categories are not satisfied on the dimensions of reliability (reliability) with the unfavorable category amounted to $73.1 \%$ larger than the dimensions of reliability ( reliability) in the good category of $27.6 \%$. The proportion of satisfaction level of patients Antenatal Care with the satisfied category on the dimension reliability with the poor category was $26.9 \%$ smaller than the dimension reliability with the good category, which was $72.4 \%$.

The test used is Continuity Correction with an error rate $(\alpha)$ of $5 \%$, the result is a significant value of 0.002 , then $\mathrm{Ha}$ is accepted so that it can be said that there is a relationship between the dimensions of Reliability (reliability) with service satisfaction Antenatal Care

Table 1.10 Relationship of Responsiveness Dimensions with Satisfaction Antenatal Care Service

\begin{tabular}{|c|c|c|c|c|c|c|c|}
\hline \multirow{3}{*}{$\begin{array}{r}\text { Dimensi } \\
\text { on of } \\
\text { Respon } \\
\text { siveness }\end{array}$} & \multicolumn{4}{|c|}{ Kepuasan } & \multirow{2}{*}{\multicolumn{2}{|c|}{ Total }} & \multirow{3}{*}{$\begin{array}{c}\rho \\
\text { value }\end{array}$} \\
\hline & \multicolumn{2}{|c|}{ Tidak Puas } & \multicolumn{2}{|c|}{$\overline{\text { Puas }}$} & & & \\
\hline & $\mathrm{n}$ & $\%$ & $\mathrm{n}$ & $\%$ & $\mathrm{n}$ & $\%$ & \\
\hline Undecent & 16 & 2,7 & 6 & 7,3 & 22 & 100 & 0,010 \\
\hline Decent & 11 & 3,3 & 22 & 6,7 & 33 & 100 & \\
\hline Quantity & 27 & 9,1 & 28 & 0,9 & 55 & 100 & \\
\hline
\end{tabular}


The results showed that the proportion of satisfaction level of Antenatal Care patients with the unsatisfied category on the responsiveness dimension (responsiveness) with the unfavorable category was $72.7 \%$ greater than the responsiveness dimension (responsiveness) in the good category of $33,3 \%$. The proportion of the satisfaction level of patients Antenatal Care with the satisfied category on the dimension responsiveness (responsiveness) with the unfavorable category was $27.3 \%$ smaller than the dimension responsiveness (responsiveness) with the good category, which was $66.7 \%$.

The test used is Continuity Correction with an error rate $(\alpha)$ of $5 \%$, the result is a significant value of 0.010 , then $\mathrm{Ha}$ is accepted, so it can be said that there is a relationship between the dimensions of Responsiveness with the satisfaction of services Antenatal Care.

Table 1.11 Relationship between the Assurance Dimensions and Satisfaction of Antenatal Care Services.

\begin{tabular}{llllllll}
\hline Dimensi & \multicolumn{4}{c}{ Satisfaction } & \multirow{2}{*}{ Total } & \multirow{2}{*}{$\begin{array}{c}\mathrm{P} \\
\text { value }\end{array}$} \\
\cline { 2 - 6 } $\begin{array}{c}\text { Assurance } \\
\text { (Jaminan) }\end{array}$ & $\mathrm{n}$ & $\%$ & $\mathrm{~N}$ & $\%$ & $\mathrm{n}$ & $\%$ & \\
\hline Undecent & 9 & 90,0 & 1 & 10,0 & 10 & 100 & \\
\hline Decent & 18 & 40,0 & 27 & 60,0 & 45 & 100 & 0,005 \\
\hline Quantity & 27 & 49,1 & 28 & 50,9 & 55 & 100 & \\
\hline
\end{tabular}

The results showed that the proportion of satisfaction level of patients Antenatal Care with the unsatisfied category on the dimension assurance with the unfavorable category was $90.0 \%$ greater than the dimension assurance ( guarantee) in the good category of $40.0 \%$. The proportion of satisfaction level of patients Antenatal Care with the satisfied category on the dimension assurance with the poor category was $10.0 \%$ smaller than the dimension assurance with the good category, which was $60.0 \%$.

The test used is the Fisher's Exact Test with an error rate $(\alpha)$ of $5 \%$, the result is a significant value of 0.005 , then $\mathrm{Ha}$ is accepted so that it can be said that there is a relationship between the dimensions of Assurance and satisfaction of services.
Table 1.12 Relationship between Empathy Dimensions (Empathy) Satisfaction of Antenatal Care Services

\begin{tabular}{llllllll}
\hline \multirow{2}{*}{$\begin{array}{l}\text { Dimension } \\
\text { of }\end{array}$} & \multicolumn{4}{c}{ Satisfaction } & \multirow{2}{*}{ Total } & \multirow{2}{*}{ Value } \\
\cline { 2 - 6 } Empathy & $\mathrm{n}$ & $\%$ & $\mathrm{n}$ & $\%$ & $\mathrm{~N}$ & $\%$ & \\
\cline { 2 - 7 } & Unsatisfied & \multicolumn{2}{c}{ Satisfied } & & \\
\hline Undecent & 15 & 75,0 & 5 & 25,0 & 20 & 100 & \multirow{2}{*}{0,009} \\
\hline Decent & 12 & 34,3 & 23 & 65,7 & 35 & 100 & \\
\hline Quantity & 27 & 49,1 & 28 & 50,9 & 55 & 100 & \\
\hline
\end{tabular}

The results showed that the proportion of satisfaction levels of patients services antenatal care within the dissatisfied category, the dimension empathy (empathy) with the unfavorable category was $75.0 \%$ greater than the dimension empathy (empathy) in the good category was $34.3 \%$. The proportion of the satisfaction level of services antenatal care with the satisfied category on the dimension empathy (empathy) with the unfavorable category was $25.0 \%$ smaller than the dimension empathy (empathy) with the good category, which was $65.7 \%$.

The test used is Continuity Correction with an error rate $(\alpha)$ of $5 \%$, the result is a significant value of 0.009 , so $\mathrm{Ha}$ is accepted, so it can be concluded that there is a relationship between the dimensions of Empathy (Empathy) and the satisfaction of services Antenatal Care. Table 1.13 Relationship between Tangible Dimensions (Physical Evidence) and Satisfaction of Antenatal Care Services

\begin{tabular}{ccccccccc}
\hline \multirow{2}{*}{ Dimension of } & \multicolumn{3}{c}{ Kepuasan } & & Total & $\begin{array}{c}\rho \\
\text { value }\end{array}$ \\
\cline { 2 - 5 } Tangible & Tidak Puas & \multicolumn{2}{c}{$\begin{array}{l}\text { Pua } \\
\text { s }\end{array}$} & & & & \\
\cline { 2 - 7 } & $\mathrm{n}$ & $\%$ & $\mathrm{n}$ & $\%$ & $\mathrm{n}$ & $\%$ & \\
Undecent & 21 & 77,8 & 6 & 2,2 & 27 & 100 & \\
\hline Decent & 6 & 21,4 & 22 & 8,6 & 28 & 100 & \\
\hline Quantity & 27 & 49,1 & 28 & 0,9 & 55 & 100 & \\
\hline
\end{tabular}

The results showed that the proportion of satisfaction levels of patients antenatal care with dissatisfied categories on the dimension tangible (physical evidence) with a poor category was $77.8 \%$ greater than the dimensions. tangible (physical evidence) in the good 
category was $21.4 \%$. The proportion of satisfaction level of patients antenatal care with the satisfied category on the dimension tangible (physical evidence) with a bad category was $22.2 \%$ smaller than the dimension tangible (physical evidence) with a good category, which was $78.6 \%$.

The test used is Continuity Correction with an error rate $(\alpha)$ of $5 \%$, the result is a significant value of 0.000 , so $\mathrm{Ha}$ is accepted so that it can be said that there is a relationship between the dimensions of Empathy (Empathy) and the satisfaction of Antenatal Care services.

\section{Discussion}

1. The Service Quality.

Results showed that as many as $61.8 \%$ of respondents had a good perception and $38.2 \%$ of respondents had a poor perception.

It can be seen from the research results that the dimensions of reliability, responsiveness, assurance, empathy, and tangible which are the 5 dimensions of service quality are by good standards even though they still exist. some of the gaps are perceived by respondents.

2. Reliability Dimensions (Reliability)

The results of the study showed that as many as $52.7 \%$ of respondents had a good perception and $47.3 \%$ of respondents had a poor perception.

According to the opinion (Purwoastuti and Walyani, 2015) that the dimension of Reliability is good, that is, officers can carry out the promised services appropriately and reliably, for example; prompt and precise examination, treatment and care services, proper service schedules, and straightforward service procedures.

3. Responsiveness Dimensions

The results of the study show that as many as $60 \%$ of respondents have a good perception and $40.0 \%$ of respondents have a poor perception.

Dimension Responsiveness According to Hardiyansyah (2011) a good consists of indicators of responding to each customer who wants to get service, officers perform services quickly, precisely, and carefully, and all customer complaints are responded to by officers. ${ }^{9}$ This is also in line with Purwoastuti and Walyani, 2015 who argue that the dimension Responsiveness is the ability to help customers and provide services quickly or responsively, for example; the ability of doctors, midwives or nurses to respond responsively to patient complaints, officers provide clear and easy to understand information, fast action when patients need them. ${ }^{10}$

In his journal Purwati (2016) explains that a bad response will give a bad impression to the service recipient. Whereas service providers must prioritize customer needs. With a good response, it will establish a good relationship between service providers and service recipients so that the patient satisfaction obtained will be spread through word of mouth. ${ }^{11}$

The use of services by service users in service is determined by the personal needs of the service user and the experience obtained. So a bad experience will give a bad impression which causes customers to be reluctant to make repeat visits because they feel disappointed and expectations of service providers are not achieved ${ }^{10}$.

4. Dimensions of Assurance (Guarantee)

The results of the study show that as many as $81.8 \%$ of respondents have a good perception and $18.2 \%$ of respondents have a poor perception.

According to (Purwoastuti and Walyani (2015) good assurance is that officers must have knowledge or politeness and the ability their generate trust and confidence, for example; medical knowledge and ability to determine the diagnosis, staff skills at work, courteous and friendly service, security assurance, and social status confidence $^{10}$.

Research conducted by Trimurthy, (2008) explains that a health center officer in providing services to patients or customers must be done professionally. Professional is a reflection of ability (competence), namely knowing (knowledge), skills (skills), can be done (ability) supported by experience (experience). One of the abilities a Puskesmas officer must have in providing services is the technical ability or skills of a person to complete his / her duties by the 
service procedure or Standard Operating Procedure (SOP) ${ }^{12}$.

In line with research conducted by Solang, Lohoraung, and Purwandari, (2012) that the attitude of health staff when meeting, for example smiling and greeting in a friendly manner, pregnant women will feel comfortable with the hospitality given. It also needs to be supported by good service quality, what health workers do to pregnant women related to the healing process, or reduce the complaints felt by pregnant women ${ }^{13}$.

5. Dimensions of Empathy (Empathy)

The results showed that $60.0 \%$ of respondents had a good perception and $40.0 \%$ of respondents had a poor perception.

According to (Purwoastuti and Walyani (2015) a good dimension of empathy should have a sense of care, give personal attention to patients, for example; give special attention to each patient, care for patient complaints, care for all patients regardless of status ${ }^{10}$.

In their journals Solang, Lohoraung and Purwandari, (2012) explains that if staff/officers always prioritize 3S (smile, greetings, and greetings), and approach pregnant women by creating a friendly atmosphere with pregnant women, it will increase interest in re-visits here it means that patients get satisfied with the services they receive $^{13}$.

Satisfaction is often seen as an important component of health care. Friendliness and enjoyment can affect patient satisfaction and availability to return to health facilities ${ }^{14 .}$

6. Tangible Dimensions (Physical Evidence)

The results of the study showed that as many as $50.9 \%$ of respondents had a good perception and $49.1 \%$ of respondents had a poor perception.

According to Purwoastuti and Walyani, (2015) that a good dimension tangible (physical evidence) includes several indicators, namely the appearance of physical facilities, equipment, personnel, and communication media, for example; cleanliness, tidiness, and comfort of the room, interior and exterior arrangement of the room, completeness, preparation and cleanliness of tools, appearance, cleanliness, and appearance of officers ${ }^{14}$. This is in line with the opinion Hardiyansyah (2011) which states that indicators tangible (reliability) include the appearance or apparatus of officers in serving customers, the convenience of providing services, convenience in service processes, disciplinary officers or apparatus in providing services, easy access to customers in service requests ${ }^{15}$.

The facilities at the Puskesmas need attention. This includes the appearance of services which are not only limited to the physical appearance of the magnificent building but also the appearance of the officers and the availability of supporting facilities and infrastructure. Therefore, the midwife should complete her appearance by wearing an identification card as an identifier so that it is recognized by the patient conducting the examination ${ }^{16}$.

In his journal Ayubi year 2009 explains that the quality of the structural attributes included in the direct evidence dimension, namely the completeness of the facilities, received the lowest assessment, wherein this situation it was found that the completeness of health service facilities was most often a complaint about the community because it could be objectively identified ${ }^{1}$.

Apart from the facilities, Puskesmas infrastructure, and the appearance of the midwife, the environment around the Puskesmas must also be kept clean. In his journal Hafizurrachman (2009) states that to improve the cleanliness of facilities is to intensify the efforts of officers cleaning service to work harder or intensive supervision in addition to the efforts of the hospital to invite patients or visitors to keep the environment clean ${ }^{5}$.

7. The satisfaction of Antenatal Care Services The

Analysis of the results showed that respondents who received services Antenatal Care $49.1 \%$ of the Godong 2 Health Center said they were not satisfied and $50.1 \%$ said they were satisfied. 
According to Windra (2010) good quality or service quality affects the healing process or reduces complaints felt by pregnant women. If pregnant women are satisfied with the services used, pregnant women will continue to use these services. Lack of quality of services provided by health workers such as timeliness of service which includes waiting time and processing time, ease of getting services, for example, the number of officers serving, not washing hands before and after providing services and officers also often forget to ask about complaints felt by mothers pregnant at the time of examination ${ }^{17}$.

So service satisfaction is closely related to the frequency of visits pregnant women, if health workers in providing services to satisfy the expectations of pregnant women, it will affect the frequency of visits of pregnant women in carrying out pregnancy examinations ${ }^{10}$.

Thus, if pregnant women who do Antenatal Care at Puskesmas Godong 2 are satisfied with receiving services, they will continue to make repeat visits so that the coverage of Antenatal Care will increase.

Customers do have to be satisfied because if the customer is not satisfied with the services provided he will look for another more satisfying place. This can be done by providing quality services that can meet the needs of patients ${ }^{18 .}$

In a research journal conducted by Nurasih, Nurrochmi, and Ukayah year 2014 it is stated that the attitude of the midwife is not good enough to cause dissatisfaction. This will have an impact on the use of Puskesmas facilities so that government policies to reduce MMR (Maternal Mortality Rate) and IMR (Infant Mortality Rate) will not be achieved ${ }^{19}$.

\section{Conclusion}

1. In the dimension of reliability (reliability) of 55 respondents, there were 29 (52.7\%) respondents who had good perceptions.

2. On the dimension responsiveness (responsiveness) of 55 respondents, there were $33(60.0 \%)$ respondents who had good perceptions.
3. In the dimension assurance, from 55 respondents, there were 45 (81.8\%) respondents who had good perceptions.

4. In the dimension empathy (empathy) of 55 respondents, there were 33 (60.0\%) respondents who had good perceptions.

5. In the dimension tangible (physical evidence) of 55 respondents, there were 28 $(50.9 \%)$ respondents who had good perceptions.

6. On the service quality of 55 respondents, there were $34(61.8 \%)$ respondents who had good perceptions.

7. On the satisfaction of services Antenatal Care from 55 respondents, there were 28 $(50.9 \%)$ respondents who had good perceptions.

8. The p-value on the dimension reliability is 0.002 , the dimension responsiveness is 0.010 , the dimension assurance is 0.005 , the dimension empathy is 0.009 , and the dimension tangible (physical evidence) is 0.000 and the $\mathrm{p}$-value for service quality is 0.001 . So it can be concluded that the dimensions of service quality have a relationship with service satisfaction in Antenatal Care

\section{References}

1. Ayubi (2009) 'Penilaian Kualitas Pelayanan Puskesmas Dengan Model

Donabedian

2. Dinas Kesehatan Jawa Tengah (2017) Profil Kesehatan Provinsi Jawa Tengah. Semarang.

3. Kemenkes RI (2017) Data dan Informasi Profil Kesehatan Indonesia. Jakarta. doi: 10.1111/evo.12990.

4. Kemenkes RI (2018) 'Hasil Utama Riskesdas 2018', p. 88

5. Hafizurrachman (2009) 'Kepuasan Pasien dan Kunjungan Rumah Sakit.', pp. 7- 10.

6. Muflihatin, I., Chairina, R. R. L. and Wicaksono, A. P. (2017) 'Hubungan Kepuasan Ibu Hamil dengan Motivasi dalam Melakukan Kunjungan Antenatal Care'

7. Mursyida, R. F., Mawarni, A. and Agushybana, F. (2014) 'Kepuasan Ibu Hamil Dan Persepsi Kualitas Pelayanan Antenatal Care Di Puskesmas Tanjung Kabupaten Sampang Madura', pp. 174-181 
8. Maria, A. (2015) 'Sikap Dan Komunikasi Bidan Terhadap Tingkat Kepuasan Ibu Hamil Pada Pelaksanaan Antenatal Care', pp. $136-141$

9. Hardiyansyah (2011) Kualitas Pelayanan Publik. Yogyakarta: Gava Media.

10. Purwoastuti, E. and Walyani, E. S. (2015) Mutu Pelayanan Kesehatan dan Kebidanan. Yogyakarta: Pustaka Baru Press.

11. Purwati, S. (2016) 'Faktor-Faktor Yang Berhubungan dengan Kepuasan Ibu Pada Pelayanan KIA di UPTD Puskesmas Japah Kecamatan Japah Kabupaten Blora tahun 2016', p. 123.

12. Trimurthy, I. (2008) 'Analisis Hubungan Persepsi Pasien Tentang Mutu Pelayanan Dengan Minat Pemanfaatan Ulang Pelayanan Rawat Jalan Puskesmas Pandanaran Kota Semarang'.

13. Solang, S., Lohoraung, A. and Purwandari, A Hubungan Kepuasan Pelayanan Antenatal Care Dengan Frekuensi Kunjungan Ibu Hamil Di Puskesmas Kombos Kecamatan Singkil Kota Manado', 4(1), pp. 349-357.

14. Setitit, L., Wantania, J. and Kaunang, W. J..P. (2017) 'Hubungan Antara Mutu Pelayanan Dengan Kunjungan Ibu Hamil K4 di Poli Kesehatan Ibu Dan Anak Rumah Sakit Umum Daerah MAPPI Provinsi Papua', pp. 76-91

15. Hardiyansyah (2011) Kualitas Pelayanan Publik. Yogyakarta: Gava Media.

16. Susmaneli, H. and Triana, A. (2014) 'Dimensi Mutu Pelayanan Kebidanan terhadap Kepuasan Pasien Program Jampersal Quality Dimensions of Midwifery Care on Patient Satisfaction Jampersal ( Delivery Assurance ) Program', (5).

17. Windra (2010) 'Hubungan Kepuasan Ibu Hamil Terhadap Pelayanan Bidan Dengan Motivasi Melakukan Antenatal Care Di Puskemas Ngasem'

18. Hizrani (2012) 'Analisis Kepuasan Pasien Rawat Inap Terhadap Mutu Pelayanan dan Hubungannya Dengan Minat Beli Ulang di RS X Jakarta'

19. Nurasih, Nurrochmi, E. and Ukayah, A. (2014) 'Faktor-Faktor Yang Mempengaruhi Tingkat Kepuasan Ibu Bersalin Terhadap Pertolongan Persalinan Oleh Bidan di
Puskesmas PONED Ujungjaya Tahun 2013', 2(3), pp. 25-30. 